\title{
What Languages are in Names? Exploring the Languages in Church Names in Ghana
}

\author{
By Osei Yaw Akoto ${ }^{*}$ \& Joseph Benjamin A. Afful $I^{ \pm}$
}

\begin{abstract}
Several studies over the years have employed the rhetorical question "What is in a name?" to uncover the semantic-pragmatic imports of names. This paper examines church names (ecclesionyms) which constitute part of the religioonomastic landscape of Ghana to discover the various languages embedded in them. To achieve this task, we gathered names of churches from 'online' (websites of associations of Christian churches) and 'offline' sources (posters, signages and billboards). We manually searched the data and identified all languages embedded in the church names. Guided by Akoto's (2018) globallocal model of language choice, the analysis showed that churches in Ghana generally adopt three global languages (Hebrew, Greek and Latin), a glocal language (English) and three local languages (Akan, Ewe and Ga). It is argued that the status of the global, glocal and local languages as canonical/biblical languages, an 'ethnically neutral' language and 'Ghanaian majority' languages respectively enable the churches to foreground their uniqueness. Implications for language planning in religion are discussed.
\end{abstract}

Keywords: church names, ecclesionym, glocal language, identity, language choice

\section{Introduction}

The church is central in Christianity, hence, Pan (2018) describes it as an icon in the Christian faith. It has a number of connotations or meanings. It is thus used to refer to the assembly of believers, the building in which the believers worship, and the Christian organization with distinct administrative and ecclesiastical polity (Goheen 2000, Koduah 2004). Therefore, it has narrow and broad imports, which respectively concerns either one or more than one of the meanings outlined. The meaning preferred is informed by one's purpose and the context of use. In this study, we subscribe to the broad which encompasses all the three imports. Church, is therefore, a Christian organization with distinct doctrine, leadership, liturgical practices and identity markers such as name, logo and colours with a designated place of worship. Goheen (2000, p. 228) asserts that "in ecclesiological understanding and formulation, the institutional aspect of the church has dominated throughout the history of the western church" and this understanding has become pervasive globally. Therefore, para-church organizations that are inter-denominational in nature and lack the aforementioned qualities are not regarded as churches (see Koduah 2004). One thing common to the various understandings of church is name. Church founders and planters have the

\footnotetext{
*Lecturer, Kwame Nkrumah University of Science \& Technology, Ghana.

${ }^{ \pm}$Associate Professor, University of Cape Coast, Ghana.
} 
onomastic right to name their churches to suit their vision and mission, culminating into varied synonyms as temple, centre, ministry, cathedral and the likes (Zelinsky 2002).

Since the $20^{\text {th }}$ century, scholars in onomastics in general and ecclesionomastics (the study of church names) in particular have taken keen interest in church names. Several studies over the years have employed the rhetorical question "What is in a name?" (Adjah 2011) to uncover the semantic-pragmatic imports of names. Interestingly, Van Zijl and Yadav (2011) used a 'coordinated and contrasted' version "What is in a name and what isn't?" These questions have been used across multidisciplinary fields to explore the concepts of name, name change, branding and advertisement. Inspired by these questions, we decided to explore the languages that are embedded in church names. The study of church names, ecclesionymy or ecclesionomastics remains an "onomastic terra incognita" (Fairclough 1960, p. 75), although "church names themselves are full of interest" (Stronks 1962, p. 203). While Fairclough's (1960) view was the state of the art 60 years ago, not much has changed since then compared to personal names (Adjah 2011, Huang and Ke 2016), corporate names (Muzellec 2006, Delattre 2002) and place names (Albury and Carter 2017, Mireku-Gyimah and Mensah 2015). There are a few papers on church names, which are data-based (Zelinsky 2002) or nondata-based (Stronks 1962, 1963, 1964). Stronks' earliest papers were merely a catalogue of church names. Stronks' $(1962,1963,1964)$ papers were preceded by Fairclough's (1960) data-based study in which he examined the "congregational name(s)" (p. 76) of Baptist denominations to ascertain the similarities and differences in the naming patterns of Negro and White Baptist churches in America. Related to Fairclough's study are Ferguson (1966), Rogers (1963), Stump (1986, 1988) and Zelinsky (2002) who explored church-naming patterns and practices in the United States of America.

In multilingual contexts, people are always confronted with names in varied languages. Indeed, the choice of the languages does not only reveal information about the language user, but the audience, the place where it is used and even the language itself. The effect and of a church name is most likely going to be influenced by several factors among which is the language embedded in them. Consequently, Pan (2018) investigated the translation of some multi-national churches into Chinese. This thus makes it crucial for languages in church names to be examined in order to help us establish the correlation between the languages in church names and language diversity in a country. Africa has contributed significantly to Christianity and its sustainability and spread (Koduah 2004). Consequently, the study focuses on Africa, particularly Ghana, to explore the languages embedded in the names in this multi-church country. The study seeks to explore the choice of immigrated languages and the hosted languages (Pan 2018), which can be considered the lingua ekklesia onomastica (i.e. the languages that are used in church names). The paper is guided by Akoto's (2018) classification of languages into global, glocal and local.

The rest of the paper is organized as follows. The first section provides an overview of the general linguistic landscape in Ghana. This is followed by the methods which details the data source, data collection and analysis procedures. It 
is immediately followed by the discussion of results, and concludes with implications of the paper.

\section{Overview of the General Linguistic Landscape in Ghana}

Ghana is a multilingual country which boasts approximately 80 indigenous languages usually presented in a language map (Eberhard et al. 2019). Ghana's current language repertoire makes it possible to distinguish between the maps of the languages OF and IN. The map of the languages IN Ghana is broader and more comprehensive than the map of the languages OF Ghana. The OF map shows languages that are indigenous to Ghana and Yevudey and Agbozo (2019) classify them into dominant and minority languages. It should be noted that this classification is not fixed as the status of can easily change since it is possible for a minority language to gain a 'dominant' status. Again, dominance or minority can be measured in degrees. For example, the Akan language which hitherto was described as the dominant language in southern Ghana (Obeng 1997) is now considered a local lingua franca (Yankson 2018). The OF map certainly does not mirror the current language contact situation in Ghana. The colonial and postcolonial eras witnessed an influx of some foreign languages in Ghana. Some typologies since then have been provided to explain the linguistic landscape in Ghana. Ellis and Ure (1982) suggested a high-low model of languages, where high, middle and low correlates with English only, English-Ghanaian language mixed and Ghanaian language only (Owusu-Ansah 1997). Akoto (2018) classified languages in Ghana into global, glocal and local, depending on the extent to which a language identifies itself with the Ghanaian sociocultural/linguistic context.

Unlike the IN Ghana map which remains relatively monolithic or unchanging, the OF Ghana one keeps increasing as a result of globalization, which among other things has resulted in increasing internationalization of some languages such as Chinese and Spanish. In recent times, it is common to find Chinese as part of the linguistic landscape of Ghana in both official and non-official inscriptions.

\section{Methods}

\section{The Data}

This study is part of a larger project which focuses on the religio-onomastic geography or landscape of Ghana. It is a common practice in Ghana to have main churches having varied names for their branches. Interestingly, the name of a branch of a main church can also be a name of another main Church. In Figure 1, the main church is Assemblies of God, Ghana with a branch named Higher Life Assembly. The present study is thus limited to only main churches but not the branches, contrary to previous studies such as Fairclough (1960), Ferguson (1966), Stump (1988) and Zelinsky (2002). The churches in Ghana gathered for the study are from "various national origins and diverse liturgical and theological traditions" 
(Ferguson 1966, p. 76). This justifies the representativeness of the data since these factors, among others, influence language choice in the names of churches (Crystal 1966).

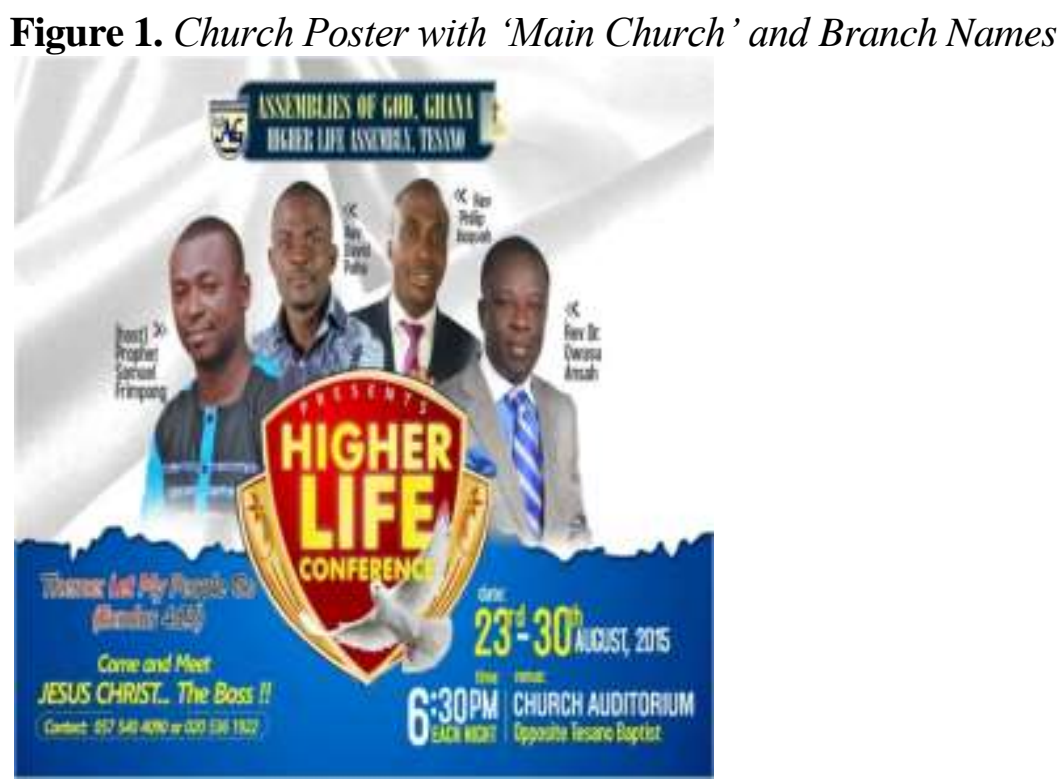

Currently, there is no central registry or directory for churches in Ghana. However, there are official umbrella bodies (Ghana Pentecostal and Charismatic Council, Ghana Christian Council and National Association of Charismatic and Christian Churches) for churches in Ghana; not many of the churches are registered members. Besides, there are no laws in Ghana that require churches to register, unlike countries such as United States of America (Stronks 1962, 1963, 1964, Zelinsky 2002). The relative absence of "complete central registries for churches" (Zelinsky 2002, p. 85) makes it an arduous task to build a data on church names in Ghana. We, therefore, collected church names from multiple sources, which included signboards, funeral posters/brochures, newspapers and the websites of church councils such as Ghana Pentecostal and Charismatic Council, Ghana Christian Council, Association of Charismatic and Christian Churches and the directory of "spiritual churches" by Opoku (1962). The data collection for the non-directory churches spans a period of ten years (2009-2019). The number of church names gathered for this study is one thousand three hundred and twentyone (1321). In spite of the vast coverage of the data, it is in no way exhaustive of the churches in Ghana. Notwithstanding, the present data can be said to be representative particularly regarding language choice in church names in Ghana, and thus lend credence to the arguments presented in the paper. The data can be described as a 'monitor data' since we continue to add new church names.

Few challenges were encountered during the data collection procedure through to the analysis. Obtaining data from official websites of the Christian groups in Ghana came with its own challenges. The membership of some associations involved para-church organizations such as Young Men's Christian Association, Young Women's Christian Association and Youth For Christ 
International Africa. These were excluded from the data. Next, it was sometimes uneasy identifying the language in some church names as a number of words have been borrowed into English from some languages. It was, therefore, difficult to ascertain whether such words were to be considered English or non-English. Two criteria were followed: foreign words (e.g., El Shaddai and Zoe) that have been anglicized in terms of orthography were considered non-English. Foreign words orthographically anglicized but have been absorbed into the English lexicon were considered English as well. Finally, we assumed that church names belong to the public domain and we thus freely took photos of relevant signages. However, there were instances when some people questioned why their permissions were not sought before taking the photographs. This, however, was resolved by apologizing, and in subsequent instances permissions were sought from the occupants of such structures.

\section{Procedure of Analysis}

The study generally focused on the kind of languages embedded in church names, and the classification of such languages (Akoto 2018). Specifically, it was interested in the identification, quantification and interpretation of the languages and language 'groups' (Akoto 2018). We read through the data and coded the church names, based on the identified languages. We adopted two strategies when we had difficulties. We used the language identification software for foreign languages (Akoto 2018) and contacted a "multilingual Ghanaian" for the indigenous languages. One lecturer in the Department of Language and Communication Sciences, KNUST, who was very instrumental in this regard could speak all the local languages found in the church names (Akan, Ewe and Ga). Such 'human language identifiers' are crucial in linguistic landscape and language choice research since it is difficult to have a software that can identify all known human languages worldwide, particularly the minority languages. The identified languages were subsequently tagged as "'En' for English", "'A' for Akan", "'E' for Ewe", "'G' for Ga", etc. After the tagging, we manually counted all the languages found and classified them based on Akoto's (2018) classification of languages (i.e., global, glocal and local). Finally, the various types whether unilingual or multilingual were also determined. The steps followed are outlined as follows:

1. Read the names one by one.

2. Consider the words in each name.

3. Identify the language source of the words.

4. Determine the degree of integration of the word into English. For example, words are considered English "on the assumption that the words in question form part of the lexicon of well-educated Anglophones [Ghanaians]" (Zelinsky 2002, p. 80) and are thus included in the English language lexicon.

5. Identify and label the languages in the church name.

6. Label the languages in the church name (e.g., 'En' for English). 
7. Count all the occurrences of a particular language in the data.

At this point, it is important to outline some observations about church names in Ghana, which also necessitated some decisions. First, name change of churches is a common practice in Ghana. In this study, we included both the 'old' and 'new' names such as World Miracle Church International and Perez Chapel International. Second, some of the churches officially have the translated version of their names as The True Worshippers' Church (Nokware Asorefo Asore). In this case, we considered the name as one but countered the languages in each case separately. Some of the churches are registered; others are not. The registration of the churches prevents the occurrences of same names for different main churches. However, a number of the churches are not officially registered and so similarity in the church names is commonplace. Some church names are distinguished based on the addition of geographical markers such as worldwide, international, global, Ghana and Africa as in The Word of Christ Chapel and The Word of Christ Chapel International -which is also the focus of another paper. Some also differed based on generics which include 'church', temple and mission, as in The Word of God Mission and The Word of God Temple. We counted each occurrence separately. Notwithstanding, for some of the names, we verified their 'sameness' or otherwise from such identity indexes as logo, motto and colours.

\section{Analysis and Discussion}

\section{Languages in Church Names in Ghana}

The paper sought to find out the languages that were employed in church names in Ghana. The analysis revealed eight languages in the data: English, Greek, Hebrew, Latin, Sanskrit, Akan, Ewe and Ga. It must be noted that all the global languages (Akoto 2018) were written in English orthography. Unsurprisingly, this finding differs from Zelinsky (2002) who observed languages such as Arabic, Hebrew, Slavic, Chinese and Hindu in the church names in America. In the present study, except English and Hebrew, all the other languages in Zelinsky were absent. This points to cross-national variation in linguistic churchscape largely influenced by linguistic and non-linguistic factors such as the linguistic diversity and the history of Christianity in the country respectively. Most crucially, the language ecology of the people is also responsible. Thus, if one has a greater number of French or Hindu community, there is a high probability that there may be names of churches in that language. For example, when the Church of Pentecost, headquartered in Ghana, established branches in francophone countries, the name was translated into French as Église de Pentecôte to identify with the dominant language in the country.

The multiple languages employed in the church names from our data set support the claim that Christianity accommodates linguistic diversity (Pennycook 2005, Karmani 2005). The quantitative profiling of the languages (as shown in Table 1) is important as it shows the value, prestige and the recognition accorded 
the languages. Landry and Bourhis (1997, p. 26) assert that "the predominance of one language on public signs [church names] relative to other languages can reflect the relative power and status of competing language groups". The "larger or smaller presence" (Coluzzi and Kitade 2015, p. 251) of any of the languages reveals the degree of attachment the people have for the language.

Table 1. Languages in Church Names in Ghana

\begin{tabular}{|l|c|c|c|}
\hline S/N & Language & Frequency & \% \\
\hline $\mathbf{1 .}$ & English & 1160 & 88.41 \\
\hline $\mathbf{2 .}$ & Hebrew & 83 & 6.32 \\
\hline $\mathbf{3 .}$ & Greek & 24 & 1.83 \\
\hline $\mathbf{4 .}$ & Akan & 19 & 1.43 \\
\hline $\mathbf{5 .}$ & Latin & 16 & 1.22 \\
\hline $\mathbf{6 .}$ & Ewe & 6 & 0.46 \\
\hline $\mathbf{7 .}$ & Ga & 3 & 0.23 \\
\hline $\mathbf{8 .}$ & Sanskrit & 1 & 0.08 \\
\hline TOTAL & & 1312 & \\
\hline
\end{tabular}

The languages employed in the church names "...manifest the influence of economic, social, cultural, ethnical(sic), and historical and globalization development" (Guihang and Bingjie 2017, p. 1) in the religious linguistic landscape in Ghana. The 'configuration of languages' (Landry and Bourhis 1997, p. 26) in the church names mirrors the multilingual environment in Ghana. It thus correlates with Ghana's linguistic diversity, as a country which accommodates multiple local and foreign languages (Dseagu 1996). This largely affirms the assertion that there is a direct correspondence between linguistic landscape and a country's linguistic composition (Landry and Bourhis 1997, Coluzzi and Kitade 2015). While Table 1 points to a diversified or multilingual linguistic landscape in the Ghanaian ecclesionymy, we noticed that English massively dominates.

Drawing on Akoto's (2018), we classified the languages found in the data into global (Hebrew, Greek, Latin, Aramaic and Sanskrit); glocal (English) and local (Akan, Ga and Ewe). In this study, we used Akan as a name of a language (Obeng 1977, Yankson 2018) rather than of an ethnic group (Appah 2003). In the ensuing sections, we discuss, first, the global languages in the church names, and then the glocal and local languages.

\section{Global Languages in Church Names}

Eberhard et al. (2019) posit that there are seven thousand one hundred and eleven $(7,111)$ languages in the world. Akoto (2018) argues that these languages can be classified into global, glocal and local depending on the degree of a language's association to a country's sociocultural context. He thus classified all indigenous Ghanaian languages as local; English and all the remaining ones as glocal and global respectively. His classification of languages is greatly influenced by the concepts of context and perspective (Brunyé et al. 2009) and the theory of social positioning (Davies and Harré, 1990) such that the language he considers as global may be considered by another person as local (Jolayemi 2015). For, 
instance, while Jolayemi (2015) and Akoto (2018) consider Hebrew as a global language, somebody in Israel will categorize it as local.

Out of the diverse global languages, only four (i.e., Greek, Hebrew, Latin and Sanskrit) were employed in church names in Ghana. Interestingly, three of the identified global languages were employed in the multilingual inscription placed on the cross of Jesus on the day of his crucifixion, as reported in John 19: 19-201.

And Pilate wrote a title, and put it on the cross. And the writing was JESUS OF NAZARETH The KING OF ThE JEWS. This title then read many of the Jews: for the place where Jesus was crucified was nigh to the city: and it was written in Hebrew, and Greek, and Latin (King James Version, Bold ours).

This suggests that the languages are employed in the church names to stress the centrality of the cross in Christianity (Stott 2012). The historical affinity between Christianity and the western world also largely explains the choice of the above-stated languages in the church names. Sawyer (2001) affirms that "language and religion share a very long and a very close history ..." as classical Arabic is linked to Islam, Hebrew for Judaism and Sanskrit for Buddhism (Pennycook 2005). Christianity, however, is said to have lost such a connection (Pennycook 2005). Pennycook (2005) suggests that language-religion mapping is not universal, although Inya (2019) thinks otherwise. More so, such a nexus is evolving where religions that resisted the use of some languages are now beginning to adopt and allow the use of other ones based on the sociocultural milieu. It is reported that Islam is beginning to welcome the use of other languages for some Islamic rituals (Karmani 2005, Mahboob 2009). We note from the data of church names that Sanskrit, a Buddhism-oriented language, has been introduced into Christianity. This is quite difficult to justify; however, it can be said to be a relative evidence of "linguistic ecumenism" (Ellos 1983, p. 1).

Christianity came to Ghana through the people of European origin. It, therefore, justifies the presence of the Indo-European languages and the absence of African languages in the global languages adopted in church names in Ghana. Crystal (1987) notes that the Indo-European languages are widespread across the globe as a result of colonialism. Furthermore, all the identified global languages are described as religious and 'old' (Crystal 1987). Although the views that certain languages are considered to be the 'language of God' and as prototypical are considered as part of linguistic myth, church namers can capitalize on that as part of their onomastic strategies for pragma-rhetorical effects. It may position such churches as the "true churches" since they are named in the language perceived to have been spoken by God and also used historically for canonical purposes. The ideologies, powers and identities ascribed to a language directly or indirectly can be associated with the users of such language.

Biblical languages may have been employed in the church names for historical links as Crystal (1987, p. 34) argues that "language provides a particular clear link with the past...This link exists even after the ability in the language has been lost..." Churches with such languages may reminisce the past records and statuses of these languages since "names with a touch of nostalgia have an appeal" (Rogers

\footnotetext{
${ }^{1}$ Holy Bible: King James Version.
} 
1960, p. 51). Arguably, the church names with words from any of the biblical languages (e.g., Hebrew and Greek) may not have been written for Hebrew or Greek readers since active and/or passive speakers of these languages are uncommon in Ghana. The presence of such languages probably is in tandem with Rainer's (2018) advice that church namers should consider Greek or Latin words they remember from seminary in order to appear appealing.

It is not surprising to find Hebrew and Greek languages employed in the Ghanaian ecclesionymy. On the contrary, we are surprised about the relatively low use of these languages in church names in Ghana given that the educated youth who dominate the Christian landscape in Ghana have a knack for these languages. They feel that these two languages must surface in a preacher's sermon such that they introduced the terms HWPS and GWPS which respectively refer to Hebrew Words Per Sermon and Greek Words Per Sermon. To them, the extent to which one is able to intersperse their sermon with Greek and Hebrew expressions marks their deepness in the Word of God. The two languages are regarded sacred as "the sacredness of the language" (Crystal 1987, p. 384) may be conferred on the churches.

\section{Glocal Language in Church Names}

English is considered a glocal language in Ghana because of its peculiar status in the Ghanaian socio-linguistic landscape (Akoto 2018, Owusu-Ansah 1995, Obeng 1997) The glocal status of English in Ghana is supported by Schneider's (2007) dynamic model of postcolonial Englishes. English in Ghana has gone through all the first four phases (i.e., foundation, exonormative stabilization, nativization and endonormative stabilization) and is currently at the final stage the differentiation stage (Nkwain, 2019, Owusu-Ansah 2012). Dseagu (1996) contends that English has been indigenized to become a national language in Ghana. He notes that English in Ghana as "an imperial and colonial language of conquest and domination has been transformed into a national language acceptable and accessible to all sections of the nation and identified with peace, progress and development" (p. 57). It is, therefore, not surprising to find it as a dominant church-naming language in the Ghanaian ecclesionymic linguistic landscape.

Given its 'dual' or bridging position as occurring in both global and local spheres (Akoto 2018), English is regarded more powerful and persuasive as it projects an enviable identity of the churches (Inya 2019). It is common to hear some Ghanaians pride themselves as belonging to an English-medium church. In fact, there are some people who lack competence in English but desire to attend English-medium churches. Moreover, there are some churches in Ghana that conduct services at separate periods on Sunday, one in English and another in a local language. Arguably, the rights of the local Ghanaian languages seem to have been ceded to the English language such that the Ghanaian linguistic landscape is markedly English. It is, therefore, not surprising that church names are considered to be part of the "sphere of influence" (Dseagu 1996, p. 58) of the English Language. In fact, literacy is construed to be "Engliacy" such that competence/ proficiency in the English language is considered synonymous to academic intelligence (Obeng 1997). This perception underscores the use of English for 
domestic/informal communication between parents and their children, especially among the educated folks (Dseagu 1996, Obeng 1997). English-oriented churches may enjoy some advantages, given that the English language in Ghana is ethnically-neutral (Dseagu 1996, Saah 1986). Dseagu (1996, pp. 59-60), therefore, acknowledges: "As a neutral language, English enjoys the unique status of being nobody's language and therefore the least associated with native traditional negative sentiments".

English has thus attained a superstar in the linguistidom particularly in Ghana, and to a large extent, the world. English church names, therefore, seek to associate themselves with this recognition that the English language has attained among all competing languages globally and locally. The status of English among the languages in church names is akin to St Paul among the saints in church names (see Ferguson 1966). Ferguson (1966), drawing on the dominance of St. Paul in the Lutheran church names in America, describes him as the "inner circle of the Apostles, and the Evangelists" (p. 82). Similarly, the English Language can be described as the inner circle of languages in church names in Ghana. As a glocal language (Akoto, 2018), English has broken through linguistic stardom. In Ghana, the superior status of English is indisputable, in terms of number of users and domains of use.

The English Language occurred as the most frequent language in the church names, supporting the increasingly global interconnection between Christianity and English (Coluzzi and Kitade 2015). Pennycook and Makoni (2005, p. 145), therefore, argue that "English is widely promoted as a modern, Christian and democratic language that can counter the despotisms of alternative worldviews". The dominance of English in the ecclesionymic linguistic landscape in Ghana can be attributed, among other things, to the fact that Christianity was introduced in Ghana by the English-speaking European missionaries (Ansong et al. 2014, Koduah 2004). The earliest churches to be established in Ghana were, therefore, named in English. It can be argued that these churches, in terms of language choice, became exemplars to the Ghanaian churches that were established later.

In Ghana, English language can be described as the religious lingua franca, which bridges the linguistic gap among Ghanaians and non-Ghanaian of different linguistic backgrounds in the Christian fraternity. In fact, some churches have English-medium services, culminating into English Services and "International Worship Centres". The choice of English can be ascribed to the 'glocal' prestige accorded the language in the religious cycles in Ghana. Some people pride themselves of belonging to an English-medium church. Hence, in recent times founders of the leading penteco-charismatic/prophetic churches who hitherto were "English language illiterate" have all learnt the language. Two phenomena now exist. The preachers either 'operate' through a local language and an interpreter translates it into English, or vice versa. All these result from the positive attitude people have towards English, which to them also enhances one's self-image. As a glocal language (Akoto 2018), English intersects both the national and international spheres. Therefore, employing English in a church's name makes it appealing to Ghanaians and other nationals both within and outside Ghana. English makes it easier for an individual who does not speak any of the Ghanaians 
local languages employed in the church names to appreciate the English-medium church names to have a sense of what is in the name -the theology and doctrines. The desire to position churches 'intersectionally' is evident in the use of 'space markers' such as 'international', 'worldwide' 'world' and 'global' in a significant number of the church names. Indeed, English language wields power and this has entrenched its superiority among languages in the world. The power, therefore, in the language attracts people to such churches, given that the language one identifies with directly affects one's identity (Akoto 2018). Guihang and Bingjie (2017) assert that "in a multilingual setting, the dominance of one language over others usually displays the higher status of its language group than other language groups. Thus, languages presented in shop signs [church names] can be informational by delivering information to attract readers' attention and are symbolic in the way of indicating status and value of such languages compared to other languages" (p. 2).

Further, the use of the English in the church names in Ghana projects such churches as cross-ethnic ones. English language is employed as an interethnic lingua franca for inter-ethnic communication among the educated Ghanaians. The preeminence of English in the ecclesionyms may be attributed to the multiethnic composition of Ghana. Suggestive in some church names 'All Nations Christian Centre', 'All Nations Full Gospel Church' and 'All Nations Pentecostal Church', English-medium church names probably indicate that they are churches for all ethnolinguistic groups locally and globally.

\section{Local Languages in Church Names}

Ghana is described as a multilingual and multiethnic state (Ansah 2014, Opoku-Amankwa 2009). Although there is lack of consensus on the total number of languages in Ghana, there seems to be an agreement among scholars on the 'majority' and minority division of the local languages (Yevudey and Agbozo 2019, Obeng 1997). Table 1 shows that three Ghanaian local languages are employed in church names in Ghana. The presence of these Ghanaian indigenous languages can be described as a mark of Ghanaianism, or Ghanaian exceptionalism in ecclesionymy which is "indicative of linguistic loyalty" (Inya 2019, p. 1157). These languages enact local identities of the churches (Fairclough 1960, Akoto 2018). Interestingly, all the churches that employed local languages are Independent African Churches with Ghanaian founder(s). For example, the churches Twer Nyame (Divine Fellowship), that is Akan and Apostoiowo Pe Dedefia Habobo (Apostolic Revelation Society) that is Ewe were founded by Ghanaians Rev. Joe Mensah Budu Colemari and Prophet Wovenu respectively (Opoku 1970). This supports the assertion that national origin of church founders influences the naming of churches (Ferguson 1966, Stump 1986, 1988, Zelinsky, 2002).

All the three local languages are majority languages in Ghana, and thus are part of the eleven government-sponsored languages taught as subjects and used as mediums of instruction in Ghanaian educational institutions (Yevudey and Agbozo 2019, Yankson 2018). Another common denominator to these three church-naming indigenous languages is that they are the only Ghanaian languages 
captured by Google for internet communication, which are potential linguistic candidates for online discourses or communication. The internet status of these languages enhances their global visibility and image. These attributes can invariably be conferred on the churches that adopt them in their names. The internationalized personae or ethos of the languages can also positively influence the corporate images of the churches that employ them. Among the local languages, these languages can be said to have attained celebrity statuses.

Therefore, adopting these local languages in church names has a number of implications. The people will have some emotional attachment (Dewaele 2008, $2010,2015)$ to such churches since they are named in the languages of their "spirits" and "souls". The relationship between language and soul has been discussed by several scholars (Dewaele 2008, 2010. 2015, Ożańska-Ponikwia 2012). Further, the members of such churches are likely to identify themselves with such churches since the churches are named in a language known to them. People who are not conversant with English language will, therefore, be attracted to such churches rather than the English-medium ones since such churches echo their ethnolinguistic identities; thereby invariably corresponding with the natural linguistic identity of the members in the respective speech communities. This resonates with the view that local languages are "emblems of group identity" (Crystal 1987, p. 42).

\section{Conclusion and Implications}

The paper which generally bothers on the religio-linguistic landscape examined language choice in church names in Ghana. Guided by Akoto's (2018) classification of languages in Ghana, the paper used data set of church names in Ghana, and classified the identified languages into global, glocal and local. The global, glocal and local languages identified were Greek, Hebrew, Latin and Sanskrit; English; and Akan, Ewe and Ga respectively.

The study has implication for policy on language choice for religious purposes in general and church naming in particular. As far back as 1960, Rogers asserted that "among the major Protestant denomination in America today almost none have rules or regulations governing selection of church names" (p. 44). Stump (1988) notes that some churches such as the Roman Catholic, Seventh-Day Adventist, Baptist churches, Jehovah's Witnesses and the Latter-Day Saints have "policies and practices in naming churches of the respective denominations" (Rogers 1960, p. 44). However, there is no policy on language choice. In Ghana, there are no "fixed onomastic principles and policies" (Rogers 1960, p. 45) on language choice. It may be argued that the liberty to choose a language in a church name is part of the freedom of worship enshrined in the 1992 constitution of Ghana. The general Christian bodies may in their own way provide principles to guide church planters on language choice in church names since that has implications for the members' theological orientation.

Language planning and policy in Ghana has mainly focused on education. Language-in-education policy in Ghana has, therefore, engendered the attention of 
scholars (Yevudey and Agbozo 2019, Opoku-Amankwa 2009, Owu-Ewie 2017) at the expense of the other domains of language use, which are equally important for the politico-socio-economic development. This study, therefore, calls for a language-in-religion policy in Ghana. It proposes that language advocates, government agencies, educators and religious actors must legislate the use of language use for religious purposes. The policy must advocate a multilingual language policy where some languages in the country will by law be employed in religious communication in order not to violate the fundamental religio-linguistic human rights of the indigenes. Over the years, Ghana Bible Society and Ghana Institute of Linguistics, Literacy and Bible Translation have tried to translate the Bible into indigenous Ghanaian languages. This is a step in the right direction, except that the act is not enforced by a language policy. It is the initiative of the local Christian missionaries and gospel propagators desire to communicate God's word into all languages of Ghana for people to understand God themselves. This issue has been tackled in mother tongue hermeneutics by such scholars as Aryeh (2016) and Kuwornu-Adjaottor (2012). We suggest that this must be legislated so that it will be binding on all religious bodies in Ghana to do same.

This study is limited to the languages in the church names. Explanations for the choice for the languages were from 'emic perspective', hence, another study can adopt an 'etic approach' by interviewing both the founders of the churches to find out from them the motivation for the choice of the languages in the church names. Again, it can also interview both members and non-members to find out their perceptions on the church names, and the impact of it on them.

\section{Acknowledgments}

We thank Dr. Melvin Djorbuah Nartey of the Department of Language and Communication Sciences, Kwame Nkrumah University of Sciences and Technology, Ghana, for helping in identifying the indigenous Ghanaian languages in the data.

\section{References}

Adjah OA (2011) What is in a name? Ghanaian personal names as information sources. African Research \& Documentation 11(7): 3-17.

Akoto OY (2018) Language choice and institutional identity: a study of the mottos of Ghanaian educational institutions. WORD 64(3): 177-190.

Albury NJ, Carter L (2017) A typology of arguments for and against bilingual placenaming in Aotearoa New Zealand. Journal of Multilingual and Multicultural Development 38(9): 831-842.

Ansah MA (2014) Language choice in multilingual communities: the case of Larteh, Ghana. Legon Journal of the Humanities 25(1): 37-57.

Ansong KD, Asante EA, Kquofi S (2014) Eulogising God in Christian worship through Akan traditional appellations: a case of Kumasi. Advances in Social Sciences Research Journal 1(8): 1-15. 
Appah CKI (2003) Nominal derivation in Akan: a descriptive analysis. Unpublished MPhil Thesis. Trondheim: Norwegian University of Science and Technology.

Aryeh DNA (2016) Inductive biblical interpretation and mother-tongue biblical hermeneutics: a proposal for Pentecostal/charismatic ministries in Ghana today. The Journal of Inductive Biblical Studies 3(2): 140-160.

Brunyé TT, Ditman T, Mahoney CR, Augustyn JS, Taylor HA (2009) When you and I share perspectives: pronouns modulate perspective taking during narrative comprehension. Psychological Science 20(1): 27-32.

Coluzzi P, Kitade R (2015) The languages of places of worship in the Kuala Lumpur area: a study on the "religious" linguistic landscape in Malaysia. Linguistic Landscape 1(3): 243-267.

Crystal D (1966) Language and religion. In S Lancelot (ed.), Twentieth Century Catholicism, 11-28. New York: Hawthorn Books.

Crystal D (1987) The Cambridge encyclopedia of language. Cambridge: Cambridge University Press.

Davies B, Harré R (1990) Positioning: the discursive production of selves. Journal for the Theory of Social Behaviour 20(1): 43-63.

Delattre E (2002) Business name changes: the French experience. Journal of Small Business Management 40(4): 360-367.

Dewaele JM (2008) The emotional weight of I love you in multilinguals' languages. Journal of Pragmatics 40(10): 1753-1780.

Dewaele JM (2010) Emotions in multiple languages. Springer.

Dewaele JM (2015) From obscure echo to language of the heart: multilinguals' language choices for (emotional) inner speech. Journal of Pragmatics 87(2): 1-17.

Eberhard DM, Simons GF, Fennig CD (Eds.) (2019) Ethnologue: languages of the world. Twenty-second Edition. Dallas, Texas: SIL International.

Ellis J, Ure JN (1982) Register range and change. International Journal of Sociology of Language 35(3): 5-23.

Ellos WJ (1983) Linguistic ecumenism: a Barthian road back from Babel. University Press of America.

Fairclough GT (1960) "New light" on "old Zion": a study of the names of white and Negro Baptist churches in New Orleans. Names 8(2): 75-86.

Ferguson CA (1966) Saints names in American Lutheran church dedications. Names 14(2): 76-82.

Goheen MW (2000) "As the Father has sent me, $i$ am sending you": JE Lesslie Newbigin's missionary ecclesiology. Utrecht: Boekencentrum.

Guihang GUO, Bingjie LI (2017) Linguistic landscape of China: a case study of the language use of shop signs in Wuhan. Studies in Literature and Language 15(1): 1-9.

Huang CY, Ke IC (2016) Parents' perspectives on adopting English names in Taiwan. Journal of Multilingual and Multicultural Development 37(8): 849-861.

Inya BT (2019) Linguistic landscape of religious signboards in Ado Ekiti, Nigeria: culture, identity and globalisation. Theory and Practice in Language Studies 9(9): 11461159.

Jolayemi D (2015) Language, literature and communication: a centenary appraisal. Journal of the School Languages 7(2): 1-10.

Karmani S (2005) Petro-linguistics: the emerging nexus between oil, English, and Islam. Journal of Language, Identity, and Education 4(2): 87-102.

Koduah A (2004) Christianity in Ghana today. Accra: Advocate Publishing.

Kuwornu-Adjaottor JET (2012) Mother-tongue biblical hermeneutics: a current trend in biblical studies in Ghana. Journal of Emerging Trends in Educational Research and Policy Studies 3(4): 575-579. 
Landry R, Bourhis RY (1997) Linguistic landscape and ethnolinguistic vitality: an empirical study. Journal of Language and Social Psychology 16(1): 23-49.

Mahboob A (2009) English as an Islamic language: a case study of Pakistani English. World Englishes 28(2): 175-189.

Mireku-Gyimah PB, Mensah AA (2015) Anglicized place names in Ghana: the case of towns in the Tarkwa mining area. The Extractive Industries and Society 2(1): 19-23.

Muzellec L (2006) What is in a name change? Re-joycing corporate names to create corporate brands. Corporate Reputation Review 8(4): 305-316.

Nkwain J (2019) Evidence of the indigenization of English in Cameroon: pitting the norm against localized forms in dissertation. In MT Mbuh, EN Samba (eds.), Bordered Identities in Language, Literature and Culture: Readings on Cameroon and the Global Space, 76-96. Cambridge Scholars Publishing.

Obeng G (1997) An analysis of the linguistic situation in Ghana. African Languages and Cultures 10(1): 63-81.

Opoku KA (1970) A directory of spiritual churches in Ghana. Research Review, Legon 7(1): 98-115.

Opoku-Amankwa K (2009) English-only language-in-education policy in multilingual classrooms in Ghana. Language, Culture and Curriculum 22(2): 121-135.

Owu-Ewie C (2017) Language, education and linguistic human rights in Ghana. Legon Journal of the Humanities 28(2): 151-172.

Owusu-Ansah L (1997) Nativization and the maintenance of standards in non-native varieties of English. In MEK Dakubu (ed.), English in Ghana, 23-33. Accra: Black Mask Publishers.

Owusu-Ansah LK (2012) Three proofs of the existence of Ghanaian English. In DF EduBuandoh, AB Appartaim (eds.), Between Language and Literature: A Festschrift for Professor Kofi Edu Yankson, 1-19. Cape Coast: University Printing Press.

Ożańska-Ponikwia K (2012) What has personality and emotional intelligence to do with 'feeling different'while using a foreign language? International Journal of Bilingual Education and Bilingualism 15(2): 217-234.

Pan H (2018) The immigration of key cultural icons: a case study of church name translation in Macao. In K Malmkjær, A Şerban, F Louwagie (eds.), Key Cultural Texts in Translation, 185-200. Amsterdam/Philadelphia: John Benjamins Publishing Company.

Pennycook A (2005) The modern mission: the language effects of Christianity. Journal of Language, Identity, and Education 4(2): 137-155.

Pennycook A, Makoni S (2005) The modern mission: the language effects of Christianity. Journal of Language, Identity, and Education 4(2): 137-155.

Rainer TS (2018) Becoming a welcoming church. B\&H Publishing Group.

Rogers PB (1963) Naming protestant churches in America. Names 11(1): 44-51.

Saah KK (1986) Language use and attitudes in Ghana. Anthropological Linguistics 28(3): $367-377$.

Sawyer J (2001) Christianity in Europe. In JFA Sawyer, JMY Simpson (eds.), Concise Encyclopedia of Language and Religion, 33-35. Oxford: Elsevier.

Schneider EW (2007) Postcolonial English: varieties around the world. Cambridge: Cambridge University Press.

Stott J (2012) The cross of Christ. InterVarsity Press.

Stronks JB (1962) Names of store-front churches in Chicago. Names 10(3): 203-205.

Stronks JB (1963) New store-front churches in Chicago. Names 12(2): 127-129.

Stronks JB (1964) Chicago store-front churches: 1964. Names 12(2): 127-129.

Stump RW (1986) Pluralism in the American place-name cover: ethnic variations in catholic church names. North American Culture 2(1): 126-140. 
Stump RW (1988) Church-naming practices among Eastern Rite Catholics in the United States. Names 36(1-2): 85-90.

Van Zijl PC, Yadav NN (2011) Chemical exchange saturation transfer (CEST): what is in a name and what isn't? Magnetic Resonance in Medicine 65(4): 927-948.

Yankson SA (2018) Language contact and change in linguistically heterogeneous urban communities: the case of Akan in Accra. LOT: The Netherlands.

Yevudey E, Agbozo GE (2019) Teacher trainee sociolinguistic backgrounds and attitudes to language-in-education policy in Ghana: a preliminary survey. Current Issues in Language Planning 20(4): 338-364.

Zelinsky W (2002) The names of Chicago's churches: a tale of at least two cultures. Names 50(2): 83-103. 